\title{
Corporation taxes in the European Union: Slowly moving toward comprehensive business income taxation?
}

\author{
Sijbren Cnossen $1,2,3,4$
}

\begin{abstract}
This paper surveys and evaluates the corporation tax systems of the Member States of the European Union on the basis of a comprehensive taxonomy of actual and potential regimes, which have as their base either profits; profits, interest and royalties; or economic rents. The current regimes give rise to various instate and interstate spillovers, which violate the basic tenets - neutrality and subsidiarity — of the single market. The trade-offs between the implications of these tenets-harmonization and diversity, respectively - can be reconciled by a bottom-up strategy of strengthening source-based taxation and narrowing differences in tax rates. The strategy starts with dual income taxation, proceeds with final source withholding taxes and rate coordination, and is made complete by comprehensive business income taxation. Common base and cash flow taxation are not favored.
\end{abstract}

Keywords Corporation tax · European Union - Tax coordination · Dual income tax · Comprehensive business income tax · Allowance for corporate equity $\cdot$ Rate of return allowance $\cdot$ Destination-based cash flow tax

JEL Classification H25 · H32 - H71 • H73 • H77

Sijbren Cnossen

cnossen@ese.eur.nl

1 CPB Netherlands Bureau for Economic Policy Analysis, The Hague, The Netherlands

2 University of Pretoria, Pretoria, South Africa

3 Professor Emeritus of Erasmus University Rotterdam, Rotterdam, The Netherlands

4 University of Maastricht, Maastricht, The Netherlands 


\section{Introduction}

The single market of the European Union (EU) should enable businesses to source anywhere, produce anywhere and sell anywhere without being hampered by double taxation and tax discrimination issues arising under the corporation taxes (CTs) of the Member States (European Commission 2015). At the same time, harmful tax competition between the Member States, which would jeopardize revenue collections, should be avoided. With this in mind, the European Commission has made various proposals for aligning the CTs in the EU to remove tax obstacles for companies operating on an EU-wide basis. Following the publication of a number of expert reports-Neumark Committee (1962), Van den Tempel (1970) and Ruding Committee (1992)—and the issue of a Code of Conduct (European Commission 1998), the European Commission (2001) proposed a Common Consolidated Corporate Tax Base (CCCTB) for European companies. The common base would be allocated to participating Member States which could then apply their own CT rate, an approach known as formulary apportionment (FA).

Neither the various reports nor the CCCTB proposal actually left the drawing board. ${ }^{1}$ Yet, some approximation or coordination of the CTs within the EU remains attractive, because it would reduce compliance costs for corporations established in more than one Member State, eliminate various forms of tax arbitrage, enable crossborder loss offsets and business restructuring, and, more generally, reduce tax-induced distortions of the intra-EU allocation of capital. The European Commission, along with the Member States, believes that these objectives should be achieved by strengthening source-based taxation of corporate income.

This paper surveys and evaluates the corporation tax systems of the Member States of the European Union on the basis of a comprehensive taxonomy of actual and potential regimes, which have as their base either profits; profits, interest and royalties; or economic rents. In doing so, it should be borne in mind that the need for CT coordination in the EU should be examined in light of the basic principles-neutrality and subsidiarity-that govern the tax relationships between the Member States (Cnossen and Bovenberg 1997). The leitmotiv of the Treaty of Rome (1957) is that the single market should ensure an efficient allocation of resources. Hence, unless expressly stipulated otherwise, CT regimes should affect saving and investment decisions as little as possible. The treaty's implicit neutrality criterion implies that the effective tax rate $[\mathrm{CT}$ and personal income tax $(\mathrm{PT})]$ on various forms of capital income, such as retained profits, dividends and interest, should be approximately the same across Member States.

By contrast, the Treaty of Maastricht (1992) enshrined subsidiarity as the guiding principle in the discussion on the assignment of policy functions in the EU. Subsidiarity proceeds from a presumption in favor of decentralization. ${ }^{2}$ Basically, policy $^{2}$

\footnotetext{
1 The CCCBT proposal was developed in greater detail in 2011 (European Commission 2011), but remained before Council. It was tabled again in 2016 (European Commission 2016a), but, thus far, no action has been taken.

2 The present formulation is contained in Article 5(3) of the Treaty on European Union (2012; consolidated version following the Treaty of Lisbon, which entered into force on 1 December 2009): "Under the principle
} 
functions, including taxation, should be exercised by the Member States, although the states are obliged to consider the effects of their actions (spillovers) on other Member States. While tax neutrality appears to require a substantial degree of tax harmonization, subsidiarity implies that each Member State should be permitted as much tax sovereignty as is commensurate with the goals of free trade and free competition in the single internal market. In other words, tax systems should require little concerted coordination, except perhaps on basic design principles. ${ }^{3}$

To set the stage for the review and the subsequent discussion of reform options, Sect. 2 develops a taxonomy of CT regimes and briefly reviews revenue developments. Against this background, Sect. 3 proceeds to examine the actual CT regimes of the Member States and attempts to distill some basic findings. Next, Sect. 4 reviews various directions for CT reform and coordination. Section 5 outlines the preferred choice and concludes.

\section{Background}

Corporate source income can be defined in three ways: (1) equity income (profits), (2) capital income (profits, interest and royalties) and (3) economic rents (above-normal returns). The various taxes that these bases permit are summed up below. Feasible options for reform often depend on the revenue consequences. Hence, corporate tax yields are also reviewed.

\subsection{Taxonomy of corporation tax regimes}

CTs in the EU are based on the OECD Model Convention with respect to Taxes on Income and on Capital (OECD 2010), which draws on the blueprint agreed to by the League of Nations in the 1920s. As befits their pedigree, the original CTs were largely designed for economies in which cross-border capital transactions were the exception rather than the rule, in which debt could be distinguished clearly from equity, and in which shareholders were natural persons generally residing in the country in which the corporation had been established. In such economies, CTs were meant to be a schedular tax on the equity income of shareholders, that is, profits. Interest was deductible in ascertaining profits and was meant to be taxed in the hands of debt holders.

\footnotetext{
of subsidiarity, in areas which do not fall within its exclusive competence, the Union shall act only if and in so far as the objectives of the proposed action cannot be sufficiently achieved by the Member States, either at central level or at regional and local level, but can rather, by reason of the scale or effects of the proposed action, be better achieved at Union level."

3 Perhaps the value added tax (VAT) is a good example. By agreeing on a tax-credit destination-based type of general consumption tax, Member States accomplished substantial neutrality regarding intra-EU trade (border tax adjustments can be made unambiguously and expeditiously). At the same time, the administration and proceeds of the tax are left in the hands of the Member States, as well as the power to set the rates (subject to a minimum). It should be emphasized, however, that the 1977 VAT agreement puts Member States in the straightjacket of an outmoded VAT which is not attuned to the realities of modern economies (for an early critical assessment, see Cnossen 2003).
} 
But globalization and capital market liberalization and innovation have turned this traditional CT model on its head. Debt has become largely indistinguishable from equity through the use of financial derivatives and hybrid instruments. Unlike equity income, interest is not taxed at the corporate level and may not be taxed at all if it accrues to foreign debt holders or exempt entities. This has led to concerns with revenue erosion and the "debt bias," which can increase the bankruptcy risk of corporations. ${ }^{4}$ The discrepancy in the tax treatment of returns that are largely identical suggests that equity income and interest should be taxed alike at the level of the corporation (De Mooij 2012).

Equity income differs from interest, however, to the extent that it consists of a normal rate of return (in other words, the opportunity cost of an investment, comparable to interest) and an above-normal rate of return or economic rent. The normal or hurdle rate of return is required to make the corporation's marginal investment just worthwhile. The CT reduces this return and, hence, affects the level of investment and, possibly, economic growth. If this is to be avoided, the normal rate of return should not be taxed and neither should interest (to the extent that it equates the normal return). By contrast, the above-normal return can be taxed without influencing the level of investment, because it can be attributed to advantages, such as favorable head starts, patents, inventions, or some form of natural monopoly - in other words, entrepreneurial advantages not enjoyed by competitors. Generally, the taxation of these advantages does not affect behavior, but the location of the underlying intangibles in, say, low-tax countries has implications for revenue collection.

Apart from the tax treatment of the returns on equity, debt and intangibles at the corporate level, there is the interaction of the CT with the PT imposed on residual income, whether dividends, interest or capital gains. Retained profits are taxed by the CT, dividend and interest under the PT. Capital gains arise if profits are retained in the corporation, which pari passu increases the value of the corporation's shares. Taxing dividends and capital gains (except if in the nature of windfall gains) at shareholder level involves double taxation, which may not be desirable, particularly if they reflect the normal rate of return.

On this basis, three kinds of CT regimes can be distinguished whose features and modalities are summed up in Table 1; they have been amply discussed in the tax literature. $^{5}$

- Conventional CT regimes (classical systems) that take equity income or profits as their base and that permit a deduction for interest paid on debt. Double taxation of profit distributions can be mitigated through dividend relief systems and

\footnotetext{
4 IMF (2016) cites various studies which conclude that a CT rate of $25 \%$ may be responsible for leverage ratios that are around 7\%-points higher compared to a system that is neutral between debt and equity.

5 For a somewhat different characterization, see Auerbach et al. (2010), which refers to Devereux and Sørensen (2006). For an early overview, see also OECD (2007). It should be emphasized that in practice the various types of income discussed here may be difficult to distinguish from each other. Thus, profits may represent the return to entrepreneurial labor that is retained in the business and realized as dividends or capital gains (Gordon and Hausman 2010; see also below under dual income taxation). Further, it may be difficult to distinguish rents from the delayed returns on past investment (quasi-rents), whose taxation affects investment incentives. Another example is the returns that accrue through tax deductible stock options which do not show up as profits. For a useful treatment, see Griffith and Miller (2014).
} 
Table 1 Options for taxing corporate source income

\begin{tabular}{lll}
\hline $\begin{array}{l}\text { Type of } \\
\text { corporation tax } \\
\text { regime }\end{array}$ & $\begin{array}{l}\text { Principal features }(\mathrm{CT}=\text { corporation tax; } \\
\mathrm{PT}=\text { personal income tax })\end{array}$ & Some literature references \\
&
\end{tabular}

A. Equity income (profits)

1. Classical system

\section{Dividend relief} systems (partial integration) 3. Full integration
system

B. Capital income (profits, interest and royalties)
Profits taxed in full after deduction of interest. Dividends net of CT taxed again at shareholder level under the PT. In practice, capital gains taxed on a realization basis at reduced PT rates

Profits taxed in full after deduction of interest, but double tax on dividends mitigated through: (a) imputation system (credit for CT against PT on dividend income grossed up by CT); (b) dividend deduction system (deduction from profits of dividends paid out, and PT on full dividend net of CT); (c) split rate system (lower CT rate on distributed profits and PT on dividend income net of CT); (d) ad hoc approaches (lower PT or partial exemption of net dividend income). Capital gains taxed as under classical system

Profits allocated to shareholders in proportion to their shareholdings. If retained, CT serves as withholding tax for PT. Windfall capital gains taxed on an accrual basis

\author{
Van den Tempel (1970) and \\ McLure (1979)
}

Bird (1987) and Cnossen (2015)

Royal (Carter) Commission on Taxation (1966), US Department of the Treasury (1977, 1992) and Campbell Committee (1981)

Sørensen (1994, 2007, 2010), Cnossen (2000) and Kleinbard (2010)

US Department of the Treasury (1992)
2. Comprehensive $\operatorname{tax}(\mathrm{CBIT})$
All capital income, corporate and non-corporate, taxed separate from labor income at uniform CT rate. Profits taxed in full after deduction of interest which may be subject to withholding tax. Dividends exempt from PT or, equivalently, taxed at shareholder level at capital income tax rate $(=\mathrm{CT})$ with credit for CT. Interest also taxed at personal level at CT rate with credit for withholding tax. Capital gains taxed at personal level on a realization basis

Profits taxed in full without deduction of interest and royalties. Dividends, interest and royalties exempt at recipient level. Capital gains taxed on a realization basis 
Table 1 continued

\begin{tabular}{lll}
\hline $\begin{array}{l}\text { Type of } \\
\text { corporation tax } \\
\text { regime }\end{array}$ & $\begin{array}{l}\text { Principal features }(\mathrm{CT}=\text { corporation tax; } \\
\mathrm{PT}=\text { personal income tax })\end{array}$ & Some literature references \\
&
\end{tabular}

\section{Economic rents (above-normal returns)}

1. Cash flow or flat tax

2. Allowance for corporate equity (ACE)

3. Rate of return allowance (RRA)
Profits taxed on a source basis, but immediate write-off of investment goods and claw back of interest and royalties. Dividends and realized capital gains taxed at (reduced) PT rate. Alternatively, above-normal return taxed on a destination basis in the country of the user or consumer of the corporation's product (called destination-based cash flow tax, or DBCFT, for short), similar to the business cash flow component of VAT. Realized capital gains taxed at (reduced) PT rates

Deduction of normal rate of return from profits net of interest; dividends and realized capital gains taxed at reduced PT rate

Deduction of normal rate of return from returns on capital income at corporate and personal level. Dividends and capital gains taxed at personal level after RRA
Meade Committee (1978), Hall and Rabushka (1995), McLure and Zodrow (1996), Bond and Devereux (2002) and Auerbach et al. (2017)

Boadway and Bruce (1984), Institute for Fiscal Studies (1991) and De Mooij and Devereux (2011)

Mirrlees (2011) and Boadway and Tremblay (2014)

by applying reduced PT rates on capital gains. Double taxation would be fully avoided if corporate profits would be allocated to shareholders proportionate to their shareholdings under a full integration system, called piercing the corporate veil. ${ }^{6}$

- CT regimes that tax profits, interest and royalties (jointly called capital income) at the level of the corporation under a dual income tax (DIT) that purports to tax all capital income, corporate and personal, once at a uniform rate. Alternatively, interest and royalties, like dividends, are not allowed as a deduction from profits and are not taxed at recipient level under a comprehensive business income tax (CBIT). Disallowing interest and royalty deductibility under the CBIT is equivalent to imposing final withholding taxes on interest and royalties at the corporate level under the DIT at rates equal to the CT rate.

- CT regimes, called cash flow taxes, whose base is confined to above-normal returns by permitting the immediate expensing of business assets while clawing back interest and royalties, or by allowing a deduction from profits of the normal return on

\footnotetext{
${ }^{6}$ Full integration is one of the normative implications of the accretion concept of income formulated by Schanz, Haig, and Simons (S-H-S-concept) (Goode 1975; Musgrave and Musgrave 1984). Full integration has been considered by various tax committees (see Table 1); the plans, however ingenious, never left the drawing board, primarily because they were considered impractical (McLure 1979; US Department of the Treasury 1992).
} 
equity (as well as interest), referred to as allowance for corporate equity (ACE) an allowance that can be extended to non-corporate capital income through a rate of return allowance (RRA). ${ }^{7}$ But for the extension, these forms of taxing economic rents are identical, if it is assumed that the value of corporate assets represents the discounted value of all their future earnings at the normal rate of return. Note that economic rents equal the business cash flow component of the value added tax (VAT), which can be derived by deducting wages from the difference between sales and purchases (including investment goods), which represents value added.

The table does not show the tax treatment of cross-border flows of corporate source income. Profits (also called active income) are usually taxed in the source country (that is, the country in which corporations carry on their business), while residual income (referred to as passive income) tends to be taxed in the residence country (that is, the country in which the corporation's shareholders, be it individuals or other (holding) companies, reside). The issues are touched upon in Sect. 3.6.

\subsection{Trends in corporation tax rates and revenues}

Prima facie, the source-based nature of CTs should induce tax rate competition between Member States, which has been called "a race to the bottom." 8 As shown in Fig. 1, following the liberalization of capital markets in the early 1990s, the simple average CT rate declined by $12 \%$-points or about one-third, from on average 35\% in 1996 to $23 \%$ in 2014. By contrast, CT ratios (revenues as a percentage of GDP) hardly declined. Since 1996, the arithmetical average ratio for 28 Member States dropped from 2.8 to $2.5 \%$ in $2014 .{ }^{9}$ Revenue even peaked around 2007 , although rates had already been lowered to around their current level. Apparently, the statutory rate reductions were offset by base broadening measures (for instance, reduced depreciation allowances), increased incorporation of firms (shifting income from PTs to CTs) and an increase in the profitability of the corporate sector (Griffith and Miller 2014). ${ }^{10}$ Individual country CT ratios differ widely, ranging from 1.4\% in Hungary, Lithuania and Slovenia to $6.4 \%$ in Cyprus, a tax haven country (European Commission 2016b).

Obviously, effective CT rates (and consequently revenues) are the product of nominal rates and tax bases. Although economic theory prescribes that corporate profits

\footnotetext{
7 This would be the so-called real ( $\mathrm{R}$ base) cash flow tax. Under a real and financial $(\mathrm{R}+\mathrm{F}$ base) variant, in(de)creases in borrowing and interest paid/received would also be taken into account. Further, under a share form of cash flow tax ( $\mathrm{S}$ base $=\mathrm{R}+\mathrm{F}$ base), the repurchase/issue of own shares and dividends paid/received would be accounted for. See Meade Committee (1978).

8 For an overview of empirical studies dealing with tax competition for mobile capital, see Leibrecht and Hochgatterer (2012) who conclude that tax rates on profits do fall due to tax competition, but that it is extremely difficult to isolate its role.

9 Note that the CT ratios do not include revenues from PTs on capital gains, interest and royalties.

10 Egger and Ruff (2015) find that countries have responded to the rate reductions by rival governments by lowering their statutory tax rates and reducing depreciation allowances. Interestingly, the authors suggest that the rise in tax competition has been caused by regional trade integration.
} 


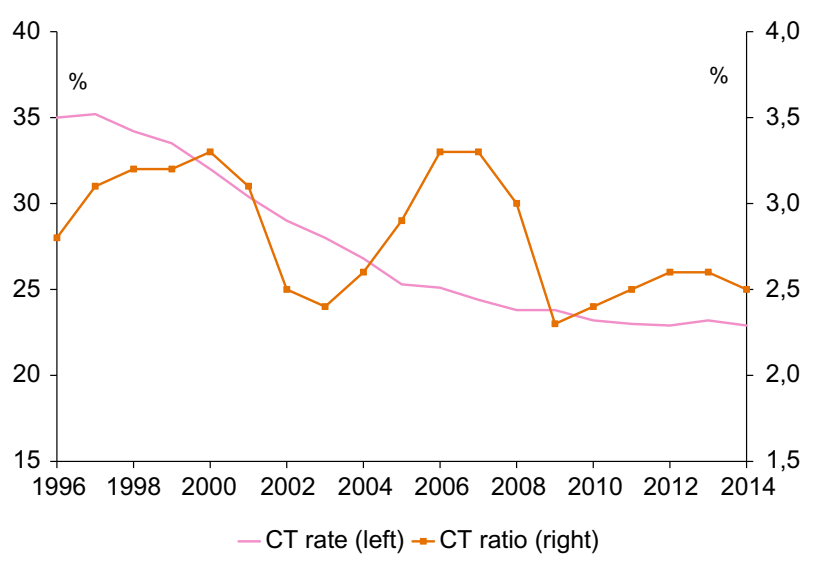

Fig. 1 European Union: trends in corporation tax rates and ratios 1995-2014. Source: European Commission (2016b). Calculations are based on simple arithmetic averages

should be calculated on an accretion basis, ${ }^{11}$ in practice taxable profits are determined on the basis of International Financial Reporting Standards (IFRS), which is the European-wide rule since 2005 for corporations listed on EU stock exchanges. The accounting principles prescribe that revenues and costs should be matched on an annual basis under the accrual system of accounting. The costs of raw materials, intermediate products and wages, as well as expenses, including interest, are deductible if incurred in earning taxable profits and in maintaining the assets used in the corporation's activities. Potential losses are taken into account in computing taxable profits, but accrued capital gains are not taxed until they are realized.

Further, in all Member States the tax base is reduced by a variety of tax incentives (provisions that provide special treatment to qualified investment projects not available to investment projects in general) primarily to promote entrepreneurship and stimulate innovation. The incentives take the form of tax holidays and reduced rates, accelerated investment recovery allowances and tax credits, and R\&D incentives. The latest tax invention is a patent box in which the whole or part of profits attributable to new inventions is taxed at a lower effective CT rate or not at all, and which reduces the tax on wages paid to researchers. ${ }^{12}$

\footnotetext{
11 The economic concept defines profits as the difference between assets and liabilities valued at market prices at the beginning and the end of the year, adjusted for profit distributions and capital contributions or payouts. Under the economic concept, economic depreciation would replace accounting depreciation and capital gains and losses would be taxed or compensated as they accrue. In the presence of inflation, moreover, adjustments would have to be made to the real value of the outstanding debt. The economic concept of profits is a very challenging design requirement that is extremely difficult to put into practice.

12 A study sponsored by the European Commission (2014; Straathof, project leader) notes that the profits from patents are protected and hence in the nature of rents, which hardly justifies favorable tax treatment. In a study covering 12 European countries, Evers et al. (2015) conclude that R\&D regimes that allow expenses to be deducted at the ordinary CT rate, as opposed to the lower patent box rate, may result in negative effective average tax rates and can thereby provide a subsidy to unprofitable projects.
} 


\section{Current tax treatment of corporate source income}

This section reviews and comments on existing CT regimes in the EU. The taxation of capital gains and closely held corporations is also evaluated as is the treatment of cross-border income flows.

\subsection{Overview of corporation tax systems}

On the basis of the taxonomy developed above, Table 2 shows how the various CT systems of the EU Member States treat equity income and debt income. ${ }^{13}$ Equity income consists of retained profits (taxed at the CT rate), dividend income (taxed at the $\mathrm{CT}+\mathrm{PT}$ rate), and capital gains (taxed at the $\mathrm{CT}+\mathrm{PT}$ rate when realized). PT dividend withholding taxes (WHTs), provisional or final, are also listed, as are the WHTs on interest paid to domestic recipients taxed under the PT. Interest may be disallowed indirectly by prescribing that for tax purposes debt cannot exceed a prescribed ratio of total capital shown in the balance sheet or by limiting the deduction to a percentage of earnings before interest, taxes, depreciation and amortization (EBITDA). If interest is not subject to a (final) withholding tax, it may not be taxed at all if paid into an exempt pension or investment fund. ${ }^{14}$

The average CT rate in the EU of $22.6 \%$ conceals widely different individual-state rates, ranging, in 2017, from a low of $10 \%$ in Bulgaria to a high of $35 \%$ in Malta. Interestingly, CT rates in the 12 new states (not counting Estonia ${ }^{15}$ ) that acceded to the EU after 1992 are on average more than 3\%-points lower than in the 15 old Member States. This suggests that new Member States use their CT rates more aggressively in stimulating investment in the corporate sector than old Member States. On the other hand, agglomeration may also matter: some old Member States are larger than most new states and, therefore, less susceptible to tax avoidance schemes (Baldwin and Krugman 2004; Garretsen and Peeters 2007).

Most systems listed in Table 1 are found in the EU. ${ }^{16}$ The majority of the Member States impose a rudimentary form of CBIT by levying a final withholding tax on interest (and dividends), which is equivalent to not allowing a deduction against profits for interest and not taxing it at recipient level. The CBITs are rudimentary, because the effective tax rates on dividend income (CT plus final withholding tax) differ from the

\footnotetext{
13 Royalty income is not shown because it accrues primarily to corporations. It does not affect the CT-PT relationship as much as the possibility of shifting corporate profits to low-tax countries.

14 For a similar earlier version of this table, see Cnossen (2005). In comparing the information in this publication with the data in the current paper, the most noteworthy development is the replacement of dividend exemption schemes by final withholding taxes at corporate level on dividends as well as interest.

15 Estonia does not levy a corporation tax as such, but imposes a tax on profit distributions, which is treated as corporation tax and not as tax withheld from the recipients of the distributions.

16 Not found are full integration (but see the subsection on capital gains and closely held corporations below), the dividend deduction and split rate systems, the cash flow tax and the rate of return allowance. A drawback of the dividend deduction and split rate systems is that the relief is automatically extended to foreign shareholders (and exempt entities), which do not pay the (additional) national PT incurred by domestic shareholders (in the absence of a final withholding tax). The cash flow tax and the rate of return allowance, discussed below, are relatively recent tax phenomena.
} 


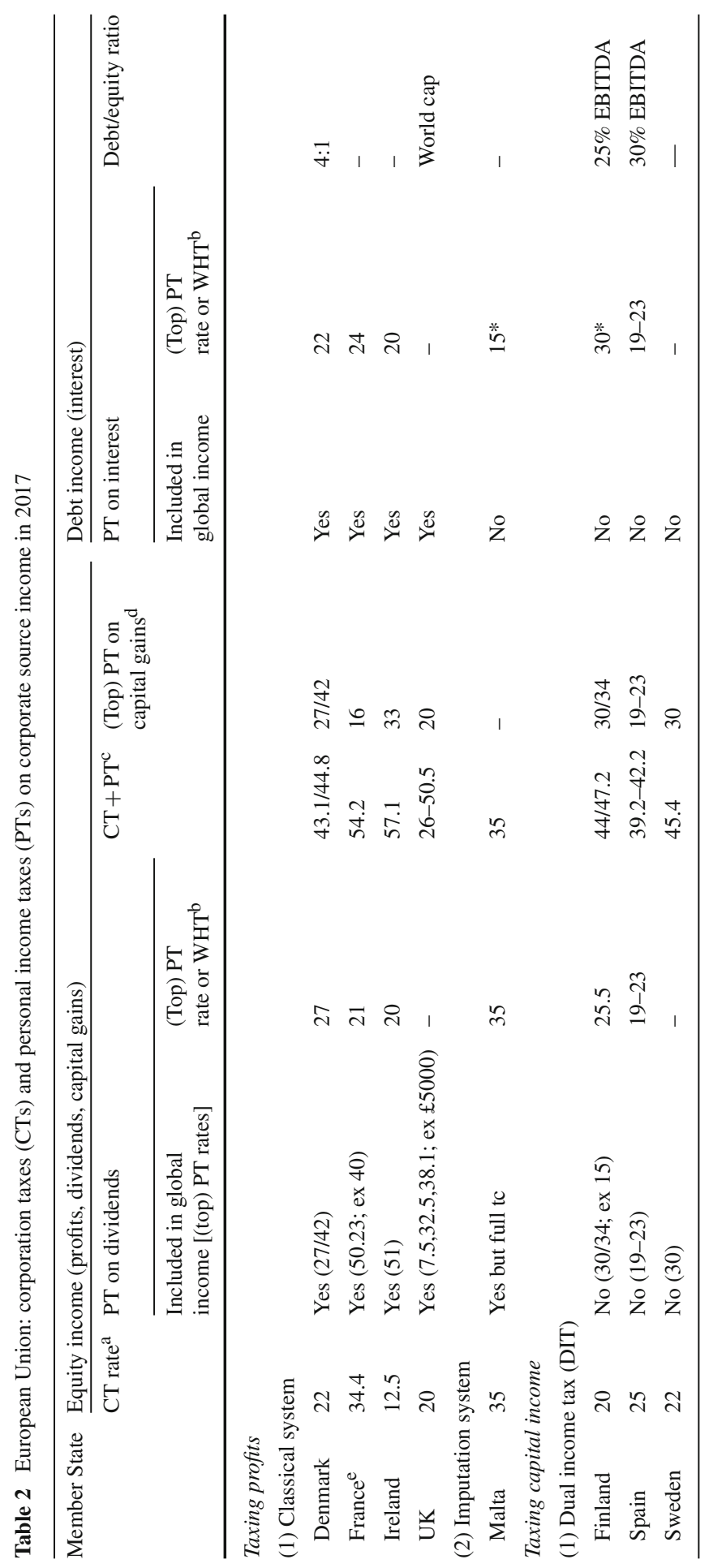




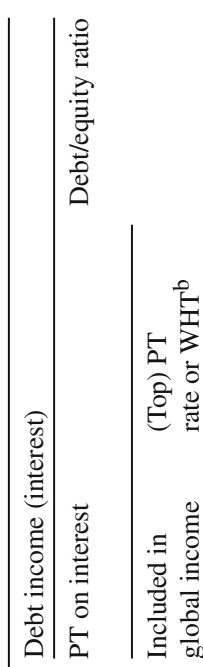

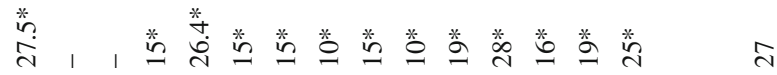

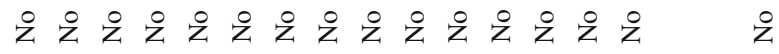

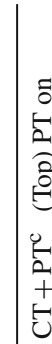

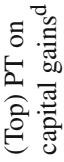

$\stackrel{*}{\stackrel{*}{*}}, \stackrel{c}{\ddagger}$

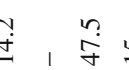

n 2

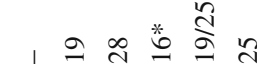

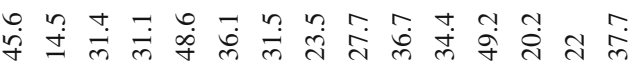

$\stackrel{\infty}{i}$

年

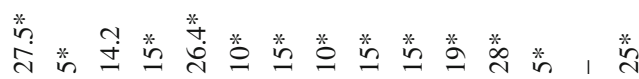

กิ 


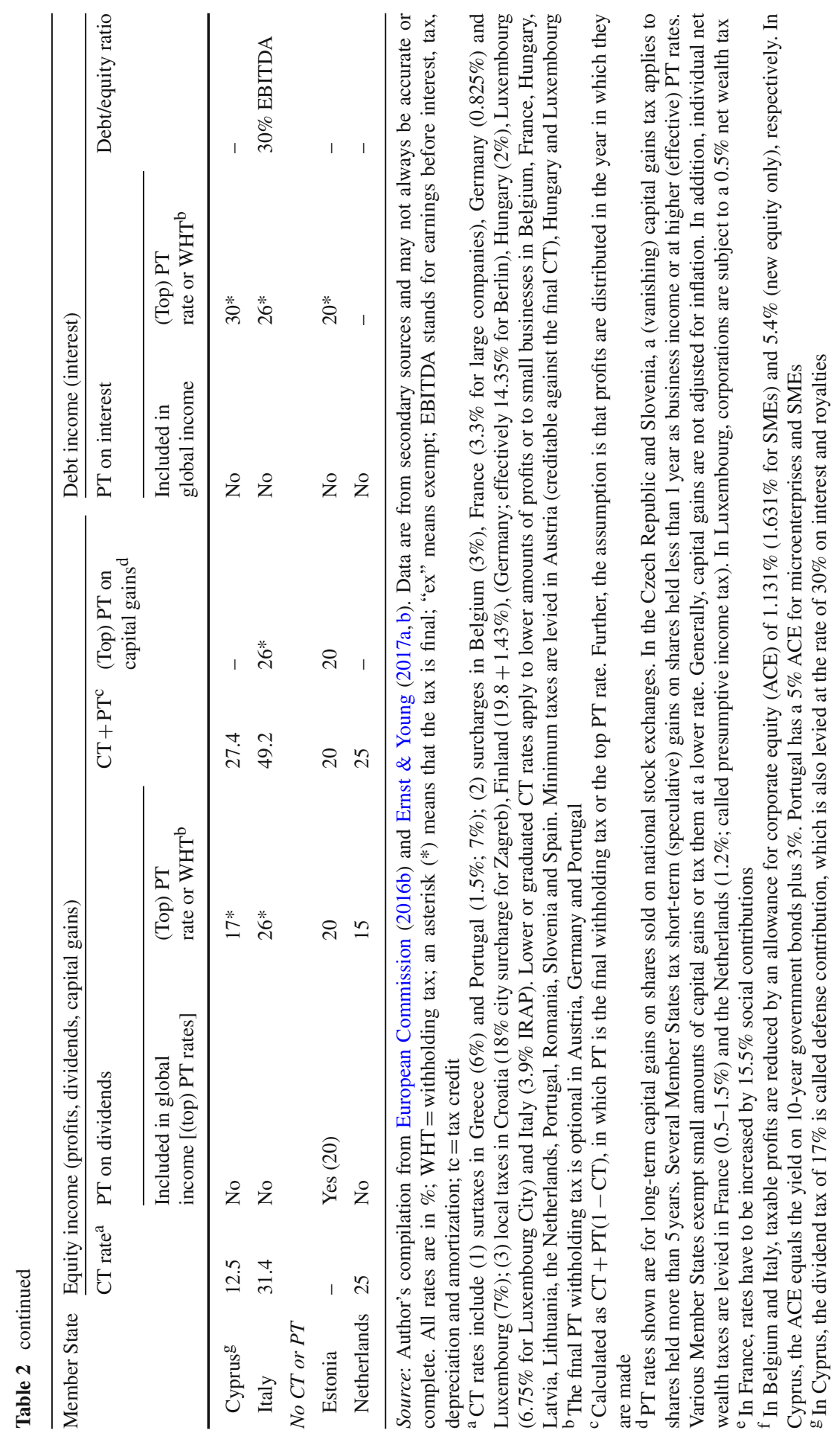


effective rates on interest (final withholding tax). Also, the withholding taxes may not apply to returns paid on shares and bonds held abroad, which are usually the subject of double tax treaties and EU directives.

Clearly, most Member States appear to have a preference for source taxation of capital income. Exceptionally, Slovakia, Sweden and the UK do not impose a withholding tax on dividends, while Bulgaria, the Czech Republic, Cyprus, Malta and the Netherlands do not tax capital gains. Interest is not subject to withholding in Bulgaria, the Netherlands, Sweden and the UK. Seven Member States do not restrict the deductibility of interest through a debt/equity ratio or EBITDA percentage (but may apply other restrictions on interest deductibility). In sum, not all Member States tax corporate source income comprehensively at the level of the corporation.

\subsection{Taxing profits (equity income)}

The so-called classical system (coined by Van den Tempel 1970) is found in four Member States. Proponents of this system regard the corporation as an entity entirely separate from its shareholders and taxed as such. Generally, no deduction for dividends is allowed when computing taxable profits. Moreover, dividends are taxed again in the hands of shareholders. The double tax is particularly high in France and Ireland where the combined CT + PT burden on dividends distributed from current profits takes up more than half of dividend income. By comparison, in six other Member States, the combined CT + PT burden is $25 \%$ or less.

The phenomenon of taxing equity income at corporate as well as shareholder level is called the "double taxation of dividends." 17 The CT and the PT on equity income both enter the wedge between the before-tax return of the corporation and the required after-tax return (the reward for saving) that must be paid to shareholders to induce them to put up their capital. Presumably, this double tax affects entrepreneurial behavior, because the wedge (and, by extension, the required return) will vary, depending on the choice of financing (retained profits, new equity, or debt) and the corporation's dividend policy (distribution or retention). ${ }^{18}$ Double taxation tends to generate a bias against profit distribution and in favor of debt financing, distorting dividend payout policies and financing decisions.

One Member State, Malta, employs an imputation system. The relief is expressed as a fraction (or percentage) of the net dividend. ${ }^{19}$ Malta has a full imputation system, which means that profits distributed to domestic shareholders are taxed at their

\footnotetext{
17 For the seminal treatment of the double taxation issue, see McLure (1979).

18 The alleged economic distortions of the classical system have not gone unchallenged in the finance literature as well as the public finance literature (Head 1997). Head concludes that on balance the distortions of the classical system are real, although perhaps not as large as sometimes thought. For a brief account and references to the literature, see Cnossen (2015).

19 This indicates the usual legal form of dividend relief. The relief can also be expressed as a percentage of the CT, showing the extent to which the double tax is mitigated, or as a percentage of the grossed-up dividend, representing the comparable tax-inclusive PT rate.
} 
marginal PT rate. ${ }^{20}$ The imputation tax credit is also available to nonresident shareholders. Imputation systems used to dominate the CT picture in the EU, especially in the 1970s and 1980s. Over time, however, they were regarded as overly complicated, while their cross-border implications were held to be discriminatory. ${ }^{21}$ In 2016, the UK abolished its imputation system, which permitted a deemed tax credit of merely 1/9th of the net dividend, and replaced it with a PT dividend exemption of $£ 5000$.

\subsection{Taxing profits and interest (capital income)}

Under the classical system, interest (and royalties) is not treated on par with the return on equity, even if debt and equity are fully substitutable. Equal treatment is achieved under regimes that tax the returns on both equity and debt at the corporate or personal level, either provisionally in the form of a dual income tax (DIT) or definitively under a comprehensive business income tax (CBIT).

Under DIT, capital income, corporate and non-corporate, is separated from labor income and taxed at a moderate, uniform rate, ideally equal to the CT rate. In the Nordic countries, the DIT was introduced on the philosophy that in a small open economy with perfect capital mobility, any source-based tax on the normal return to capital will be shifted onto domestic, immobile factors or products through an increase in the pretax rate of return required by investors. ${ }^{22}$ In this situation, it is simply not optimal for a small economy to levy any source-based tax on the normal return. Although corporate capital is not fully mobile, the degree of mobility is so high that it is advisable to keep any source-based tax low, absent international tax coordination. If, for revenue and distributional reasons, the top PT rate cannot be reduced to the level of the lower CT rate, the obvious solution therefore is to tax capital income on a schedular basis. Further, capital market innovation in conjunction with tax arbitrage implies that it is not feasible to tax capital income effectively at different tax rates. Hence, the decision to tax capital income at a moderate uniform tax rate, basically equal to the $\mathrm{CT}$ rate.

The Nordic Member States, Finland and Sweden, now have 25 years of experience with dual income taxation. ${ }^{23}$ The DITs in these countries, however, are not as pure

\footnotetext{
${ }^{20}$ More than full relief is possible if dividends are paid out of exempt profits without imposing a compensatory tax at the corporate level. Presumably, for this reason, Malta imposes a $15 \%$ tax on dividends paid out of untaxed profits.

21 Thus, in Manninen, the European Court of Justice (2004) held that the Finnish imputation system violated the free movement of capital principle laid down in the Treaty of Rome (1957), because the imputation tax credit was not available for dividends received from foreign corporations. Hence, the Court argued, this deterred taxable persons in Finland from investing in other Member States. Apparently, the Maltese regime has not (yet) been challenged on this ground. For a detailed review of imputation systems, see Cnossen (1997).

22 This paper does not dwell on the incidence of the CT, but for a review of the theoretical and empirical literature, see Gravelle and Hungerford (2011) who suggest that in the US economy perhaps $40 \%$ of the burden falls on labor. By contrast, Clausing (2013) strongly argues that there are reasons to suspect that workers have thus far remained insulated from their countries' corporate tax policies. In her view, the corporation tax is primarily born by capital.

23 The DIT was pioneered in Denmark in 1987, but subsequently the country strayed from the DIT path by moving some way back to a comprehensive income tax.
} 
as the Norwegian DIT. ${ }^{24}$ Corporate profits and other capital income are taxed at the same rate in Norway, but other capital income is taxed at somewhat higher PT rates in Finland and Sweden. Further, capital gains are taxed twice in Finland and Sweden to the extent that no account is taken of the CT that is levied on retained profits. Spain is the latest member of the DIT club. ${ }^{25}$

Fifteen Member States may be said to have some form of CBIT. As shown in Table 2, they impose a final withholding tax (WHT) at the corporate level on interest paid to residents or exempt interest altogether from the PT (Bulgaria, Croatia). Dividends, too, are subject to final withholding (or exempt as in Slovakia) and not taxed under the PT. ${ }^{26}$ These CBITs are not pure, however, because the effective tax rates differ for various types of capital income. Retained profits are taxed at a lower rate than distributed profits, while interest tends to be taxed at rates similar to the CT rate. With some exceptions, this is also true of capital gains, although deferral implies that effective rates are lower.

\subsection{Taxing economic rents}

The allowance for corporate equity (ACE) is the only cash flow tax in practice today. ${ }^{27}$ The ACE system purports to tax only pure profits by providing a deduction from profits, conventionally computed, equal to the shareholders' funds (generally, the corporation's total equity capital, including taxable profits net of CT) multiplied by an appropriate nominal interest rate set by the government but reflecting a normal market rate of return on, say, medium-term government bonds. ${ }^{28}$ Since the ACE closely resembles normal profits, its deduction from total taxable profits means that the CT is confined to pure profits from infra-marginal investments. ${ }^{29}$

\footnotetext{
${ }^{24}$ For a discussion of the Norwegian system, see Sørensen (2007), and for an analysis of the Finnish system see OECD (2008).

25 Outside the Nordic area and Spain, various countries have introduced DIT elements in their tax systems. See Eggert and Genser (2005) and Genser and Reutter (2007). Further, the German Council of Economic Experts (2003), Sinn (2004) and Spengel and Wiegard (2004) have proposed variants of the DIT for Germany. Keuschnigg and Dietz (2007) did so for Switzerland. Griffith et al. (2010) touch on the issues in Mirrlees (2010) and Kleinbard (2010) provides a very thorough analysis of a hypothetical DIT in the US context.

${ }^{26}$ Since dividends are taxed fully at corporate level without regard to the PT rate structure, the relief in the form of a flat final withholding tax is proportionately greater for high-income-bracket PT payers than for low-income-bracket PT payers. Austria, Germany and Portugal mitigate this regressive effect by permitting low-income-bracket PT payers to opt for full double taxation of their dividend income (with a credit for any PT withholding tax imposed at the corporate level).

27 The ACE system was conceived by Boadway and Bruce (1984) and further developed by the Institute for Fiscal Studies (1991).

28 This comes close to but does not equal the economic rent, which still cannot be measured with sufficient precision for tax purposes (Boadway 2015).

${ }^{29}$ Early proponents of the ACE approach (Devereux and Freeman 1991; Gammie 1991) point out that in present value terms the base of the CT is identical to the base of an annual pure profits tax for two reasons. First, the equity allowance permits any schedule of depreciation allowances without altering the present value of the tax payments associated with the cash flow of an investment. High depreciation allowances would result in a lower amount of shareholders' funds and hence a lower allowance and vice versa. Second, both corporations and shareholders can borrow at the appropriate nominal interest rate to offset different
} 
Belgium exempts the normal return from CT in the form of an ACE, called "notional interest on corporate capital." The interest is set at the rate payable on 10-year government bonds issued in the previous year. Presumably, this rate reflects the normal rate of return on capital. The rate-1.131\% in 2017 but $1.631 \%$ for SMEs-is applied to the corporation's "risk capital," that is, its equity shown on the balance sheet. Belgium introduced the ACE system to stimulate the self-financing capability of corporations, but did not extend it to unincorporated businesses and private investors. ${ }^{30}$ The ACE in Cyprus is equal to the yield on 10-year government bonds plus $3 \%$. Italy confines the ACE to new equity. For some time, Croatia also had an ACE system but abolished it for reasons that are not entirely clear (Keen and King 2002).

By exempting the normal return on capital, the ACE regime does not affect real investment. Also, financing decisions - choosing between equity and debt or retained earnings and new equity - are not distorted, while the distortion of the organizational form in which the business is conducted-corporate versus non-corporate form-is mitigated. However, not taxing the normal return implies that the CT rate has to be higher if CT revenues are to be maintained. This should exacerbate tax avoidance through profit shifting.

In comparing the ACE system with the CBIT, Bond (2001) opines that in a world with increasing mobility of physical capital, the user cost of capital may no longer be the only route through which the CT influences the level of domestic investment. If, as is likely, multinational companies dominate in the earning of economic rents, their discrete location decisions would also be influenced by the statutory rate or, more precisely, the Effective Average Tax Rate (EATR) which can be shown to be a weighted average of the statutory tax rate and the Marginal Effective Tax Rate (METR). Under an equal-yield assumption, the statutory rate would have to be higher under the ACE tax, which would distribute corporate tax payments toward relatively profitable companies. By contrast, a lower-rate CBIT would leave profitable multinational companies with lower tax bills. In this situation, a government in an open economy may achieve a higher level of domestic investment by lowering the statutory rate and accepting a broader tax base, even though this results in a higher cost of capital.

Estonia goes even further than Belgium by exempting the whole of corporate profits from CT. Instead, a $20 \%$ tax is levied upon the distribution of corporate profits to individuals or other corporate entities. The profits distribution tax in Estonia, which is recorded as CT revenue, yielded 1.7\% of GDP in 2014 (European Commission 2016b). Interest is also taxed at $20 \%$ at the PT level. Finally, the Netherlands exempts dividend income in full (although it still levies a withholding tax at corporate level, which is creditable against other income). Instead, in the 2001 reform, it introduced a

Footnote 29 continued

profiles of tax payments or distributions, respectively. Further, the ACE approach preserves neutrality under inflation, because the interest rate is set at its full nominal level.

30 In an analysis of the Belgian system, Aus dem Moore (2014) shows that the expected reduction in leverage is confined to large firms. The author also estimates an increase of some $3 \%$ in the rate of (financial) investment due to the introduction of the ACE. 
$1.2 \%$ net wealth tax, which it calls income tax (not shown in the table) as a substitute for the PT on dividend income and interest. 31

\subsection{Taxing capital gains and closely held corporations}

As shown in Table 2, 22 Member States tax capital gains on shares, but no Member State makes a systematic attempt to alleviate the double tax on retained profits by allowing shareholders to increase the acquisition price of shares by the corporation's retained profits net of CT (as Norway does). Further, the capital gains tax rates are statutory or nominal rates. Deferral and various tax base preferences result in effective capital gains tax rates that are lower than the nominal rates and also lower than the CT + PT burden on profit distributions. Accordingly, shareholders should have a preference for capital gains over dividends, which may be expected to affect payout policies.

The treatment of capital gains is of special interest in the case of closely held corporations in which shareholders work in the company as managers and, hence, can decide whether profits (constituting capital as well as labor income) are retained (taxed by the CT plus a deferred tax when capital gains are realized), paid out as dividends $(\mathrm{CT}+\mathrm{PT})$, or as wages (PT). Applying the CT only would induce managers/shareholders to adopt the corporate form for their labor income generating activities, which would then be taxed at a generally lower rate than the income of ordinary wage earners. To prevent this from happening, profits of closely held corporations can be taxed in full under the PT (full integration), or split into labor income (subject to the PT) and capital income (subject to the CT) under the DIT.

No Member State practices full integration for closely held corporations. ${ }^{32}$ Instead, most Member States adopt an ad hoc approach by arguing that profit distributions are taxed twice under the CT and the PT, which roughly equals the PT on labor income. The concern therefore is mainly with capital gains attributable to profit (=labor income) retention. To prevent labor income from being effectively taxed less when sheltered in corporations, at least 13 Member States distinguish capital gains realized on the sale of (non-traded) shares (which represent a controlling interest, called substantial holding, in closely held corporations) from capital gains realized on the sale of ordinary (widely held) shares (generally, quoted on national stock exchanges). The former gains are taxed differentially higher than ordinary gains. Details can be found in Table 3 .

Nordic DITs provide the most consistent treatment of capital and labor income that accrues jointly in closely held corporations, as well as proprietorships and partnerships. Taxable profits, conventionally computed, are split into a capital income component and a labor income component (if the sum of the two components exceeds the first bracket of the labor income tax, the rate of which equals the CT rate), and taxed on

\footnotetext{
31 See Cnossen and Bovenberg (2001). The 2001 tax reform exacerbated the discrimination against equity holdings. The return on equity is now taxed twice, under the CT and the presumptive PT, while the return on debt is taxed only once, under the PT.

32 Full integration is practiced under the "partnership method" of Subchapter S of the US Internal Revenue Code. S corporations with 100 shareholders or less enjoy the benefit of incorporation while being taxed as a partnership. Cooper et al. (2015) estimate that "pass-through" businesses, such as partnerships and S corporations (heavily concentrated among high earners) generate over half of US business income.
} 
Table 3 European Union: personal income tax treatment of substantial holdings and unquoted shares in 2016

\begin{tabular}{|c|c|c|c|}
\hline Country & Type of income & Criterion & Tax treatment \\
\hline Austria & Capital gains & $1 \%$ ownership & Taxed at $25 \%$ \\
\hline Bulgaria & Capital gains & Unquoted shares & Taxed at $10 \%$ \\
\hline Czech Republic & Capital gains & $5 \%$ ownership or votes & $\begin{array}{l}\text { Taxed at } 15 \% \text {, but exempt } \\
\text { after } 5 \text { years }\end{array}$ \\
\hline France & Capital gains & Active shareholders & Taxed as business income \\
\hline \multirow[t]{2}{*}{ Germany } & Interest & $10 \%$ ownership & Taxed at progressive rates \\
\hline & Capital gains & $1 \%$ ownership & $\begin{array}{l}\text { Taxed at } 60 \% \text { taxed as } \\
\text { business income }\end{array}$ \\
\hline Greece & Capital gains & $0.5 \%$ ownership & Taxed at $15 \%$ \\
\hline \multirow[t]{2}{*}{ Ireland } & Dividends & Less than 5 owners & Taxed as labor income \\
\hline & Interest & Shareholders/directors & Treated as dividends \\
\hline Italy & Dividends, capital gains & $\begin{array}{l}\text { Listed companies: } 2 \% \\
\text { voting rights or } 5 \% \\
\text { ownership; otherwise: } \\
20 \% \text { voting rights or } \\
25 \% \text { ownership }\end{array}$ & $\begin{array}{l}49.72 \% \text { taxed at } \\
\text { progressive rates }\end{array}$ \\
\hline \multirow[t]{2}{*}{ Luxembourg } & Dividends & $10 \%$ ownership & $\begin{array}{l}\text { Taxed at half the average } \\
\text { rate }\end{array}$ \\
\hline & Capital gains & 10\% ownership & Taxed \\
\hline Netherlands & Dividends, capital gains & $5 \%$ ownership & Taxed at $25 \%$ \\
\hline Portugal & Capital gains & Unquoted shares & Taxed at progressive rates \\
\hline Sweden & Dividends, capital gains & Active shareholders & $\begin{array}{l}\text { Prescribed amount taxed } \\
\text { at } 2 / 3 \text { of flat capital } \\
\text { income tax rate; excess } \\
\text { taxed as labor income }\end{array}$ \\
\hline United Kingdom & Capital gains & $\begin{array}{l}5 \% \text { ownership and voting } \\
\text { plus employment in the } \\
\text { company }\end{array}$ & $\begin{array}{l}\text { Taxed at } 10 \% \text { up to } £ 10 \\
\text { million on a lifetime } \\
\text { basis }\end{array}$ \\
\hline
\end{tabular}

Source: Harding (2013), Annex C; and author's additions

a current basis. Specifically, the capital income component of profits is calculated by applying a presumptive rate of return to the value of all business assets, called the gross method (Norway), or to the value of all assets minus liabilities (equity capital), referred to as the net method (Finland). ${ }^{33}$ The amount thus calculated is deducted from total profits, and remaining profits are considered as labor income. As explained by Sørensen (2010), the choice between the two methods is largely a choice between investment neutrality and minimizing opportunities for tax arbitrage. Tax arbitrage is less of an issue under the gross method, because the presumptive rate of return is

\footnotetext{
33 Under the gross method, the presumptive return is reduced by the interest actually paid to calculate taxable net capital income. The gross return, furthermore, is subtracted from total profits (increased by the interest actually paid) to calculate taxable labor income. Under the net method, in contrast, presumptively determined capital income is subtracted directly from net profits (that is, net of interest actually paid) to ascertain taxable labor income.
} 
applied to a base that is not influenced by the financing structure of the business. The net (equity) method, on the other hand, is more conducive to investment neutrality because it does not encourage debt-financed investment if the government sets the presumptive rate of return above the going interest rate.

\subsection{Intra-EU capital income flows}

The previous paragraphs analyzed the domestic tax treatment of corporate source income. However, owners of shares, bonds and intangibles, be it corporate entities or individuals, may reside in states other than the state in which the paying corporation carries on its business and the residence states may assert a right to tax the dividends, interest, royalties and capital gains accruing to its residents. The division of the taxing rights of source and residence states is the subject of bilateral tax treaties and EU directives agreed to by the Member States. In practice, dividends are taxed not only by the source state (under the CT and by withholding taxes, if any) but also by the residence state (under the PT and CT on portfolio dividend income). Most residence states tax shareholders on realized capital gains. The returns on debt and intangibles, that is, interest and royalties, are taxed by the residence state and, if a withholding tax applies, by the source state.

Table 4 shows the general bilateral treaty withholding tax (WHT) rates in the EU on dividends, interest and royalties between non-related parties. For each Member State, the treaty WHT rates are listed that have been agreed with the Member State that provided the largest amount of inward foreign domestic investment over the period 2008-2014 (OECD 2014) as a proxy for portfolio investment in the same direction. ${ }^{34}$ Regarding dividends, most WHT rates are fixed at 15\%. Sixteen Member States impose a WHT on interest at various rates, while royalty income tends to be exempted or subject to $5 \%$ WHT.

By contrast, EU directives proscribe the use of withholding taxes on dividends, interest, royalties and capital gains between related parties in favor of residence states. Thus, the Parent-Subsidiary Directive (European Council 1990; revised in 2003 and 2006) eliminates nonresident withholding taxes on dividend payments among related companies with a minimum shareholding of $10 \% .{ }^{35}$ Similarly, the Interest-Royalty Directive (European Council 2003a) eliminates nonresident withholding taxes on intra-firm interest and royalty payments if the beneficial owner is effectively subject to tax on interest and royalties received in the corporation's Member State of establishment. Further, the Merger Directive (European Council 2009) eliminates the taxation of capital gains realized by corporations and shareholders upon an intra-EU merger or acquisition. Finally, the Savings Directive (2003b) provides for the exchange of information on cross-border interest accruing to individuals, which can then be taxed in the residence state.

\footnotetext{
34 Accordingly, the withholding tax (WHT) rate on dividend income paid by a Cypriot company to a portfolio shareholder in the UK is $0 \%$, as indicated in the first box on the top left hand side of Table 4.

35 Various new Member States continue to impose a 5\% withholding tax on dividends, but then their CT rates are lower than in old Member States.
} 
Table 4 European Union: treaty withholding tax (WHT) rates in 2017 on dividend, interest and royalty payments to non-related parties in member states providing the largest amount of foreign direct investment during 2008-2014
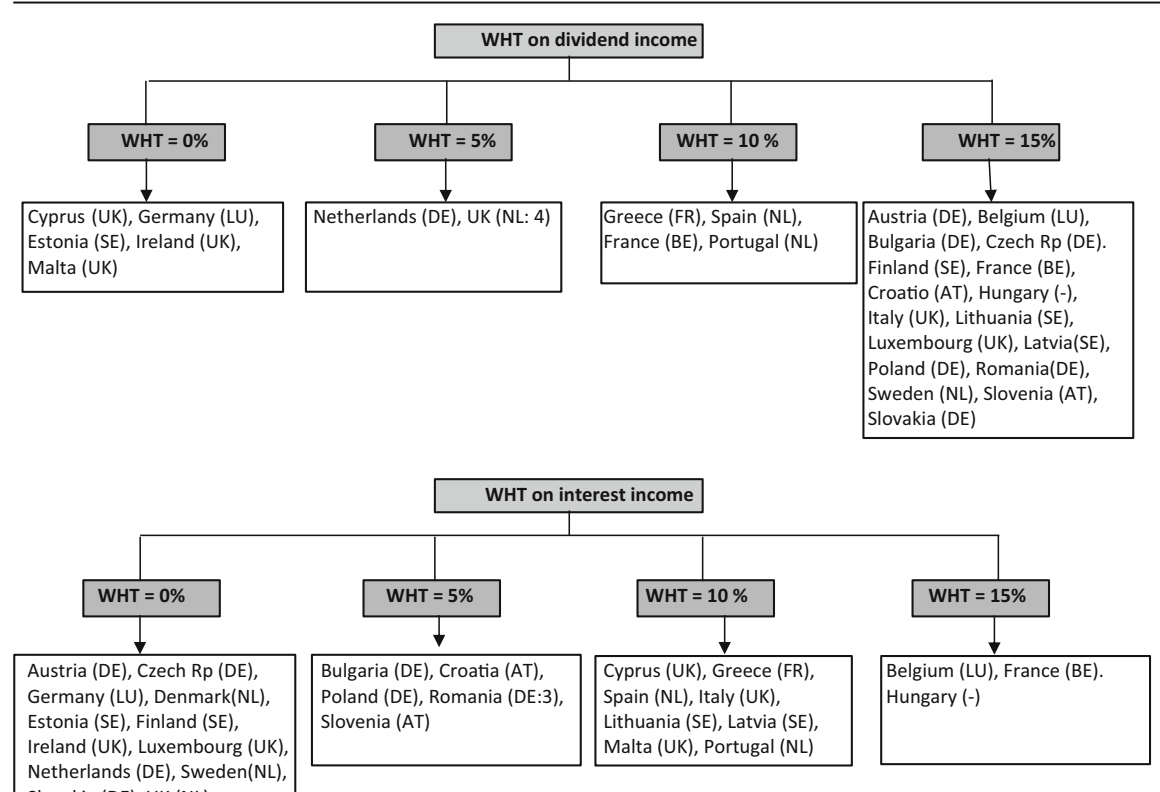

DE) Sweden (NL), Slovakia (DE), UK (NL)

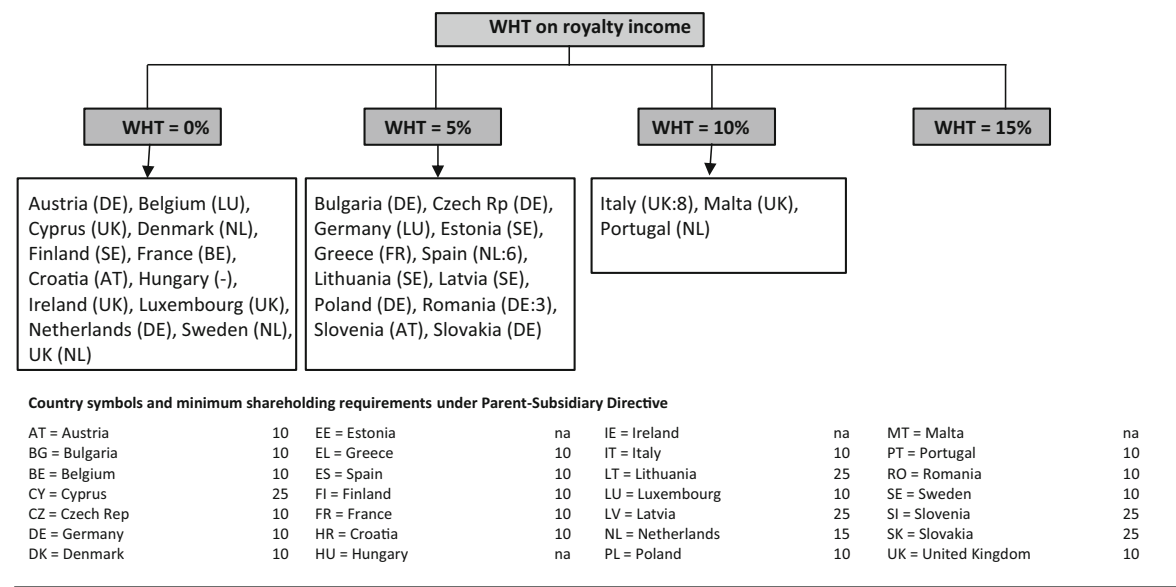

Sources: Ernst \& Young (2017a,b) and OECD (2014). Statistics on foreign direct investment flows are not available for Bulgaria, Cyprus, Croatia, Latvia, Lithuania, Malta and Romania. In the event, the WHT rates on dividend, interest and royalty payments to share, debt and patent holders in the most likely FDI-providing Member States have been inserted in the table. "UK (NL:4)" means that the WHT on dividend income paid by a UK company to a portfolio shareholder in the Netherlands is $4 \%$ instead of $5 \%$ (the headline rate). Mutatis mutandis the same applies to "Romania (DE:3)" (twice), "Spain (NL:6)" and "Italy (UK:8)" 
Accordingly, EU Member States apply the source as well as the residence principle in taxing corporate source income. As is well known, the residence principle permits capital export neutrality (CEN), which implies that the tax system does not affect the choice between investing at home or abroad (Musgrave 1969). On the other hand, the source principle promotes capital import neutrality (CIN). This implies that both resident and nonresident investors face the same tax burden on an investment in a particular source country. The source principle is easier to apply in practice than the residence principle because the taxable income originates in the Member State collecting the tax.

In a situation of perfect capital mobility, the residence principle equalizes pre-tax rates of return; in other words, at the margin, capital costs are the same in different countries. The source principle, in contrast, tends to equalize the post-tax rates of return of savers residing in different states. Whether one principle is economically superior to the other principle depends on whether users of capital (business firms) or suppliers of capital (savers) are more sensitive to differences in returns. Business firms are likely to be more sensitive to differences in capital costs than savers are to differences in net returns. Hence, the residence principle (that is, capital export neutrality) seems a more important efficiency objective to pursue than the source principle (that is, capital import neutrality). ${ }^{36}$

The subsidiarity principle, however, indicates a preference for source country taxation over residence-country taxation of corporate source income in the EU. By implication, capital import neutrality is favored over capital export neutrality. In a single market, however, in which capital and persons can move freely, the distinction between these two kinds of neutrality tends to become blurred. Administrative considerations, moreover, support the argument for source country taxation. ${ }^{37}$ Further, the experience in federal countries, such as the USA and Canada, indicates that different CTs can exist in a single market without internal borders. ${ }^{38}$

\subsection{Some important findings}

The analysis in this section yields some important findings, which can be summed up as follows.

- Basically, the taxable return on corporate investments is defined in terms of equity income (profits), but increasingly Member States levy final withholding taxes on

\footnotetext{
${ }^{36}$ In an early contribution, Horst (1980) showed that if the elasticities of supply and demand for capital are positive but finite, the optimal tax lies somewhere between the point that ensures capital export neutrality and the point that conforms to capital import neutrality. It should be noted that CEN is not achieved if residence countries limit the foreign tax credit and if they defer domestic tax on the business income of foreign subsidiaries until repatriation.

${ }^{37}$ For administrative reasons, source country taxation is also indicated if Capital Ownership Neutrality (CON) is the policy goal. This concept, developed by Desai and Hines (2003), posits that cross-country ownership patterns should not be distorted by the tax system. CON may be attained under worldwide foreign tax credit income taxation and tax base harmonization, but also under a territorial system with tax base harmonization. Obviously, feasibility considerations favor the latter approach.

38 These countries, however, have an overarching federal CT, which should iron out some of the differences in state and provincial CTs.
} 
interest (and dividends) paid to domestic share and debt holders-income items that are subsequently exempted.

- In the domestic context, therefore, 15 Member States are moving toward some form of CBIT. Within this context, however, various forms of capital income are taxed at different effective rates, which may distort savings and investment decisions. Capital income is taxed more uniformly in three Member States with a DIT. Another three Member States do not tax the normal return to capital under their ACE, which, they believe, should promote investment.

- Generally, dividends are taxed at a higher rate than interest if the earlier CT is taken into account, as it should be. This favors debt over equity. ${ }^{39}$ The higher tax on dividends can be defended if they reflect above-normal profits. The tax on dividends, which stimulates profit retention, reduces the amount of capital becoming available on European capital markets and thus hampers the development of EU share markets. ${ }^{40}$

- Capital gains are widely taxed at schedular PT rates and only upon realization, implying lower effective rates. Higher rates would be appropriate if the gains reflect economic rents or windfalls. No state takes account of the earlier CT by correcting the basis of share purchases for retained corporate profits net of CT.

- Withholding taxes are imposed on dividends paid to non-related parties abroad, but to a lesser extent on interest and royalties. Payments to related foreign corporate entities tend to be exempted from tax. Withholding tax exemptions or lower rates are granted only if the beneficial recipient is effectively taxed. Prescribed debt/equity ratios effectively limit interest payments to foreign as well as domestic debt holders.

- In all Member States, pension and investment funds are not taxed and can hence be used as conduits for not paying tax on interest or dividends if tax is not withheld at corporate level or the withholding taxes on these payments are refundable. ${ }^{41}$ In addition, the tax exempt status of institutional investors affects their portfolio choice and thereby the ownership structure of firms.

Although various efforts have been made in recent years to reduce the discrimination of profit distributions by lowering the PT on dividends, and the preferential treatment of debt and royalties by imposing (final) withholding taxes at corporate level, most neutrality shortcomings have not yet been eliminated fully or have been removed through ad hoc measures (for example, debt/equity ratios) that leave the basic conventional CTs largely intact. Further, much of the tax literature is in favor of not taxing the hurdle rate of return on capital in the form of an ACE. What should Member States do?

\footnotetext{
39 IMF (2016) finds that "[e]ven taking account of the PT, most tax systems for which we have data still favor debt over equity."

40 Just like the double tax on dividends, the tax treatment of pension premiums in Germany interferes with EU-wide capital mobility. Most pension premiums are deductible from taxable profits in Germany only if retained in the firm as so-called book reserves. This tax treatment provides established German firms with relatively cheap equity finance at the expense of new starting firms (not only in Germany but also in other Member States) that have to attract new equity.

41 IMF (2016) notes that "[i]n many countries, a significant share of investment is sheltered from PT, such as those by institutional investors."
} 


\section{Directions for corporation tax reform and coordination}

This section examines the various options for CT reform and coordination in the EU more closely. CT regimes that tax the normal rate of return (DIT, CBIT, formulary apportionment) are discussed first, followed by regimes that exempt the normal rate of return (ACE, destination-based cash flow tax).

\subsection{Dual income tax (DIT)}

A pragmatic scenario for further CT (and other capital income tax) reform and coordination in the EU could start with a DIT, as found in Finland, Norway, Sweden and Spain, under which capital income, not just corporate income, would be taxed once at a single rate (different for each Member State) equal to the CT rate. This would mitigate the distorting effects of current differential CT + PT systems on corporate financial and investment policies. Agreement could be pursued in the EU on a minimum DIT rate. Under these DITs, dividends paid out of fully taxed profits should be exempted at shareholders' level (which would reduce the debt bias), while dividends paid out of exempt profits should be subject to a compensatory tax at the CT rate.

A differentially higher tax on dividends could be contemplated, however, to the extent that the dividends reflect above-normal returns. This extra tax could be confined to residents by imposing it at shareholder level as is done in Norway. The Norwegian shareholder's income tax, as it is called (Sørensen 2005), taxes dividend income in full under the PT but permits a deduction of a rate of return allowance equal to the interest on medium-term government bonds. Accordingly, this rate of return allowance is taxed only once, namely at corporate level, while economic rents are taxed twice. ${ }^{42}$ As a result, as noted by Kleinbard (2010), Norway does not make a distinction between labor and capital income, but between the normal return on capital and all other income. ${ }^{43}$

As pointed out by Sørensen (2005), an advantage of this approach is that it eliminates the incentive for income shifting between jointly accruing labor and capital income in closely held corporations in a manner that limits investment distortions. Furthermore, it obviates the need to make a distinction between "active owners" of closely held corporations (owning the business as well as managing it—simultaneously earning labor and capital income) and "passive owners" (financing, but not owning the business and not involved in running it). ${ }^{44}$ The distinction between labor and capital income remains relevant for unincorporated businesses, but only if the total income exceeds the first bracket of the labor income tax schedule, the rate of which equals or closely reflects the CT rate.

\footnotetext{
42 By contrast, the normal rate of return is not taxed under the Mirrlees (2011) proposal for a rate of return allowance (RRA). Note that investment incentives would still be distorted under the Norwegian shareholder's tax to the extent that the normal rate of return is taxed.

43 But note that Norway still taxes income from immovable property at progressive labor income tax rates.

44 On the possibilities of income shifting under the (previous) Norwegian DIT, see Altstadsaeter (2007). Pirttilä and Selin (2011) argue that income shifting is still an issue in Finland.
} 
As regards interest and royalties, for the time being, the level of the creditable or final withholding taxes at the corporate level could vary between Member States in light of domestic and international policy considerations (for instance, its effect on foreign domestic investment). Provisionally, the (final) withholding tax rates could be lower than the CT rate, for instance, and not apply to foreign recipients of interest for fear of discouraging inward capital flows. Presumably, full (and final) withholding taxes on interest and royalties paid to foreign bondholders and intellectual property owners would require EU-wide coordination. Coordination with the EU's major trading partners would also be needed.

Finally, the concern that some Member States may have regarding the lower taxation of capital income compared to labor income could be addressed by adopting a net wealth tax on residents. This would raise the effective tax burden on domestic (mostly well-to-do) residents without affecting nonresidents and hence inward capital flows. In this respect, too, Norway leads the way.

\subsection{Comprehensive business income tax (CBIT)}

The extension of final interest and royalty withholding taxes throughout the EU to payments to nonresidents as well as residents would effectively tax the returns on all forms of capital, eliminate incentives for thin capitalization and the discrimination in favor of tax exempt investment and pension funds. Over time, the withholding taxes could be raised to the level of the DIT rate, which would convert the DITs into CBITs. Agreement should then be reached that interest and royalties ${ }^{45}$ are not taxed again in residence countries, which would require the abrogation of the Parent-Subsidiary Directive and the Interest-Royalty Directive. To ensure that dividends, interest and royalties are not paid out of exempt earnings (possibly escaping the tax altogether), a compensatory tax should be levied on exempt profits made available for distribution in either of these forms of return. Preferably, capital gains on shares should only be taxed to the extent that they exceed the acquisition cost stepped up by the corporation's retained profits net of the CT.

Subsequently, the narrowing of CT (and withholding tax) rates throughout the EU would eliminate incentives for transfer pricing manipulation within the EU (but not with third countries). Presumably, rate narrowing would be easier to achieve following the introduction of DITs and more comprehensive withholding taxes on interest. This reform would make the debt-equity distinction irrelevant, and greatly reduce the distinction between retained and distributed profits (depending on the treatment of capital gains).

The effective taxation of interest and royalties on par with equity income would reduce the relative tax burden on new equity-financed investment and increase the burden on debt-financed investment. Established firms and institutional investors would face relatively higher tax burdens, as would tax haven countries, but new, growing

\footnotetext{
45 As Juranek et al. (2016) argue, royalty payments can also be disallowed under the CBIT, because they cannot be used anymore to improve the investment distortion. However, the corporate tax distortion is still present as it is under DIT.
} 
firms would be taxed less heavily. If the reform were revenue neutral, nominal CT rates could be reduced, while average tax rates could perhaps be allowed to fall due to overall efficiency gains. In an important contribution to the tax literature, De Mooij and Devereux (2011) conclude that their applied general equilibrium model for the EU suggests that "if governments adjust statutory corporate tax rates to balance their budget, profit shifting and discrete location render CBIT more attractive for most individual European countries."46

\subsection{Formulary apportionment (FA)?}

Under the previous proposals, the CTs would still proceed from the separate accounting approach in determining the taxable profits of affiliated corporations in different Member States. Accordingly, profit shifting through transfer pricing manipulation would still be possible, albeit moderated by the narrowing of rate differentials. Further, provisions for the removal of tax obstacles to cross-border economic activity and business restructuring would still be needed. A comprehensive solution to these problems, if desired, can only be achieved through common base taxation.

In this connection, the European Commission (2016a) has launched a recalibrated proposal for a Common Consolidated Corporate Tax Base (CCCBT) for large multinational groups with global revenues in excess of $€ 750$ million a year. The CCCBT would be allocated to Member States on the basis of three equally weighted factors: the value of assets in a Member State, the number of employees and labor costs, and the company's destination-based sales in the Member State. ${ }^{47}$

According to the European Commission, the advantages of a CCCBT with formula apportionment (and its logical conclusion, unitary taxation) are fewer distortions, less tax arbitrage (transfer pricing) and lower compliance costs. This is disputed by Altshuler and Grubert (2010), however, whose model indicates that separate accounting causes fewer distortions than FA under capital-based formulas, which induces capital to move to low tax jurisdictions. Further, sales-based formulas induce companies to change the mix of high margin and low margin sales in a market, and also the extent to which independent resellers in low-tax countries are used. In sum, the simulations which the authors perform indicate that FA has no clear advantage over separate accounting.

The path to common base taxation would not be easy either. As pointed out by McLure and Weiner (2000) and Mintz and Weiner (2003), its introduction would give rise to serious policy sequencing and transition problems for EU Member States. Accounting conventions and institutional structures would have to be harmonized. All of these problems would be exacerbated by complex technical questions, such as defining a unitary business, choosing the appropriate apportionment formula (directly

\footnotetext{
46 By contrast, the authors also conclude that EU-wide coordination makes a joint ACE more, and a joint CBIT less efficient. Further, "[a] combination of ACE and CBIT is always welfare improving."

47 The proposal is made attractive by combining it with a 10-year long $2.7 \%$ Allowance for Growth and Investment (AGI) (identical to an ACE) for new investments financed by new equity or profit retention, and $100 \%$ expensing of R\&D costs (plus $50 \%$ for R\&D expenses up to $€ 20$ million and $25 \%$ over $€ 20$ million). Obviously, the AGI and the R\&D allowances are not integral to the CCCBT proposal.
} 
affecting the interstate allocation of revenue) and measuring the factors in the formula (precise definitions are crucial). ${ }^{48}$ Harmonization of the tax base seems less urgent than coordination of the tax rates. Perhaps formulary apportionment should therefore be left for two or more Member States to deal with as is the case in the USA and Canada.

\subsection{Allowance for corporate equity (ACE)}

Under DIT, CBIT and FA, the return on marginal investments, just making a viable economic return, would be taxed, which might harm investment. This normal rate of return is effectively exempted under the ACE, which is favored by De Mooij and Devereux (2011) as well as, more cautiously, by the IMF (2016).

Undoubtedly, the ACE system has attractive neutrality properties. ${ }^{49}$ By exempting the hurdle rate of return, marginal investments are not hampered. Similarly, the debt-equity choice is not affected by the tax system, while economic distortions through differences in depreciation between assets and industrial sectors are eliminated. Complex valuation issues are avoided, and inflation would not affect the tax base. Broad adoption of the ACE would make profit shifting through transfer pricing manipulation considerably less attractive, just like the shifting of assets and firms (mergers and inversions) or the manipulation of the debt/equity ratio.

Against these advantages, sight should not be lost of some disadvantages. Given the same rate, the ACE will generate less revenue than a conventional CT. To make up for the revenue shortfall, either the CT rate would have to be increased (magnifying the remaining distortions and tax avoidance incentives) or compensation would have to be sought elsewhere in the tax-and-expenditure system with effects that cannot be ignored. The revenue loss can be reduced by confining the ACE to new equity-financed investments (as is done in Italy), but this would aggravate the administrative complexity of the tax. Initially, immediate expensing of investments would also increase losses and with it the call for offset against past losses.

More generally, the neutrality conditions that are required for the ACE to work are met only if capital markets are perfect. To ensure investment neutrality, moreover, the government would have to share symmetrically in all gains and losses under unlimited loss carry forward and backward provisions. Further, if dividends continue to be taxed under PTs, the ACE system would favor retentions even more strongly over distributions than do other CT systems. In effect, the ACE system would then resemble a

\footnotetext{
48 For a good discussion of the intricacies and pitfalls of formulary apportionment, see IMF (2014), which observes that tax competition can become even more severe than under separate accounting (territorial) taxation. Using a numerical computable general equilibrium (GCE) model for Europe, Bettendorf et al. (2010) find that common base taxation does not yield substantial welfare gains and does not weaken incentives for tax competition.

49 For the UK, for instance, De Mooij and Devereux (2009, Table D4) have calculated that the adoption of ACE financed by a base broadening of the VAT (food and the construction of new dwellings are zero-rated in the UK, while rent on dwellings is exempt) would result in an increase of investment by $6.1 \%$ and wages by $1.7 \%$. Further, employment would increase by $0.2 \%$ and GDP by $1.4 \%$.
} 
form of dividend relief, akin to the dividend deduction system. Also, the ACE regime does not provide relief to unincorporated businesses. To be fully neutral, the ACE system would require the transformation of the PT into a personal consumption tax, which comprehensively exempts the normal return to capital. ${ }^{50}$ On the basis of these arguments, Mintz (2015) rejects an ACE for Canada. He also points out that an ACE would increase tax losses, make the corporate form even more attractive for sheltering labor income and run afoul of the US tax credit system (a point also made by Griffith et al. 2010).

\subsection{Destination-based cash flow tax (DBCFT)}

While the ACE does not affect investment in a closed economy setting, in an international context countries should still compete over tax rates, because the base would remain mobile even if confined to economic rents. To mitigate this effect, Auerbach et al. (2017) propose to shift the ACE base from its origin, the producer, to its destination, the consumer, who is less mobile. This can be done by making the ACE border adjustable by including imports in the domestic tax base and excluding exports from that base. In other words, the ACE base would equal the business cash flow component of the base of a VAT, which is a destination-based consumption tax. The authors call their proposal a destination-based cash flow tax, or DBFCT, for short. The new tax, at a rate of $20 \%$, has been tabled by the US House of Representatives Republican Task Force on Tax Reform (see Ryan 2016). ${ }^{51}$

The DBCFT would have many of the same disadvantages and advantages as the ACE, but in addition, the trading partners of a DBCFT country might consider the proposed treatment of imports and exports a form of protectionism not permitted under the provisions of the World Trade Organization (WTO) Treaty. The proponents of the new tax, however, argue that the implicit taxation of imports and the rebate of the tax on exports mean that the USA will import less and export more. This should result in an appreciation of the dollar, such that the relative prices of internationally traded and domestically produced goods and services remain the same, which should restore the ex ante situation. Buiter (2017), however, has argued that the presumed exchange rate adjustment is not robust; even a deprecation of the dollar should not be excluded. Finally, Auerbach et al. (2017) have pointed out that the effect of a DBCFT can also be achieved by introducing a VAT in the form of a Hall and Rabushka (1995) flat tax under which wages are deducted from value added leaving business cash flow, that is, the above-normal return to capital. The tax on wages could then be plowed back in the form of a reduction in employers' social security contributions which would result in an immediate reduction of labor costs.

\footnotetext{
50 Indeed, this kind of reform was recommended by the IFS Capital Taxes Group (1989) in the form of an extended personal equity plan. The Mirrlees (2011) proposal achieves the same result through its rate of return allowance (RRA).

51 For two appraisals, see Cui (2017) and Patel and McClelland (2017).
} 


\section{Concluding comments}

This review of CT systems in the EU appears to indicate that subsidiarity and neutrality in the EU are best served by the moderate, even-handed, source taxation of capital income. ${ }^{52}$ This reflects the preference of the Member States, which shore up their source-based CTs with transfer pricing rules, prescribed debt/equity ratios, prohibitions on the deferral of tax on the income of controlled foreign corporations (CFCs) and, increasingly, final withholding taxes on dividends, interest and royalties. Basically, the right to tax of residence states is confined to residual income.

However, differences in the tax treatment of various forms of capital income distort corporate financial and investment policies, involve complex administrative arrangements and induce tax competition. A pragmatic solution to these issues appears to lie in a combination of CT reform within Member States with CT coordination between Member States. A start could be made with the wider adoption of DITs under which capital income would be taxed at a moderate uniform rate (that is, the CT rate, which, subject to a minimum, could still vary between Member States), except interest and royalties on inbound investment and the use of foreign intangibles. Subsequently, agreement could be reached on expanding and converting current EU Member State treaty withholding tax rates into final taxes on interest and royalty payments with regard to foreign (as well as domestic) debt and intangibles. To prevent double taxation, residence states would then have to give up their right to tax residual income in the form of dividends, interest and royalties. Further, the EU directives on the exemption of capital income payments between related entities would have to be withdrawn. The DITs would turn into CBITs once the withholding taxes reach the level of the CT rate.

Although full taxation of interest and royalties at corporate level would seem a goal worth pursuing, gradual and concerted action is called for. Caution is advisable because the current tax-induced changes in corporate financing and intangible ownership patterns may, to a large extent, serve to reduce the distortions of real investment and saving decisions. ${ }^{53} \mathrm{~A}$ start could be made with the common $10 \%$ withholding tax on interest and royalties, also on intra-group transactions, proposed by Finke et al. (2014). ${ }^{54}$ Presumably, full source-based taxation of capital income in EU Member States would require coordination with the EU's major trading partners, particularly the USA.

The article has not come out in favor of FA, because of its distortions and complexities. Neither does it favor some form of cash flow taxation since most Member States appear to believe that the normal return on capital should be taxed. This view finds

\footnotetext{
52 For a range of arguments in favor of moderate, uniform capital income tax rates, see also Zodrow (2006, 2010). In an earlier publication Slemrod (1995) argued that an EU featuring (equal rate) source-based DITs would be more efficient than an EU featuring fully enforced residence-based taxes (if feasible of implementation) only, because the cost of enforcement is lower for the system of source-based taxes.

53 It may also lead to more aggressive tax rate competition by low-tax countries, as argued by Becker and Fuest (2012).

54 Finke et al. (2014) assess the impact of various measures to strengthen source taxation in OECD member countries. Four options are discussed: bilaterally restricting interest and royalty deductibility, replacing the deductibility of payments by an inverted tax credit system (Lodin 2011, 2013), levying withholding taxes on all interest and royalty payments, and levying withholding taxes as an anti-avoidance regulation.
} 
support in recent work on the incidence of the $\mathrm{CT}$ which is shown to fall predominantly on capital and therefore to be progressive (Clausing 2013). More generally, the scope for capital taxation from an equity perspective should not be lost sight of. ${ }^{55}$

Acknowledgements This paper is a substantial revision of a paper presented at the 71st Annual Congress of the International Institute of Public Finance (Dublin, 20-23 August, 2015), which was issued under the title Tackling Spillovers by Taxing Corporate Income in the European Union at Source, as CPB Discussion Paper 324 (February 2016) and as CESifo Working Paper No. 5790 (March 2016). For the current version, I am greatly indebted to the perceptive comments of two anonymous referees.

Open Access This article is distributed under the terms of the Creative Commons Attribution 4.0 International License (http://creativecommons.org/licenses/by/4.0/), which permits unrestricted use, distribution, and reproduction in any medium, provided you give appropriate credit to the original author(s) and the source, provide a link to the Creative Commons license, and indicate if changes were made.

\section{References}

Altshuler, R., \& Grubert, H. (2010). Formula apportionment: Is it better than the current system and are there better alternatives? National Tax Journal, 63(4), 1145-1184.

Altstadsaeter, A. (2007). The Achilles heel of the dual income tax: The Norwegian case. Finnish Economic Papers, 20(1), 5-22.

Auerbach, A., Devereux, M. P., Keen, M., \& Vella, J. (2017). Destination-based cash flow taxation. Oxford University Centre for Business Taxation, WP 17/01.

Auerbach, A. J., Devereux, M. P., \& Simpson, H. (2010). Taxing corporate income, chapter 9. In S. Adam, T. Besley, R. Blundell, S. Bond, R. Chote, M. Gammie, P. Johnson, G. Myles, \& J. Poterba (Eds.), Dimensions of tax design: The Mirrlees review (pp. 837-893). Oxford: Oxford University Press for the Institute for Fiscal Studies.

Aus dem Moore, N. (2014). Corporate taxation and investment-Evidence from the Belgian Ace Reform. Ruhr Economic Paper No. 534.

Baldwin, R. E., \& Krugman, P. (2004). Agglomeration, integration and tax harmonisation. European Economic Review, 48, 1-23.

Becker, J., \& Fuest, C. (2012). Transfer pricing and the intensity of tax rate competition. Economic Letters, 117(1), 146-148.

Bettendorf, L., Devereux, M. P., van der Horst, A., Loretz, S., \& de Mooij R. A. (2010). Corporate tax harmonization in the EU. Economic Policy, 25(63), 537-590.

Bird, R. (1987). Corporate-personal tax integration. In S. Cnossen (Ed.), Tax coordination in the European Community (pp. 227-251). Deventer: Kluwer.

Boadway, R. (2015). Tax policy for a rent-rich economy. Canadian Public Policy, 41(4), 253-264.

Boadway, R., \& Bruce, N. (1984). A general proposition on the design of a neutral business tax. Journal of Public Economics, 24, 231-239.

Boadway, R., \& Tremblay, J.-F. (2014). Corporate tax reform: Issues and prospects for Canada, Mowat Research \#88. Toronto: Mowat Centre, University of Toronto.

Bond, S. R. (2001). Levelling up or levelling down? Some reflections on the ACE and CBIT proposals, and the future of the corporate tax base, chapter 7. In S. Cnossen (Ed.), Taxing capital income in the European Union: Issues and options for reform (pp. 161-179). Oxford: Oxford University Press.

Bond, S. R., \& Devereux, M. P. (2002). Cash flow taxes in an open economy, CEPR Discussion Paper, No. 3401 .

Buiter, W. H. (2017). Exchange rate implications of Border Tax Adjustment neutrality, Discussion Paper, Economics No. 2017-10.

Campbell Committee. (1981). Final report of the Committee of Inquiry into the Australian Financial System. Canberra: Australian Government Publishing Service (AGPS).

\footnotetext{
55 As argued by Saez and Stantcheva (2017) who discuss a range of ethical considerations regarding capital taxation that are salient in the policy debate.
} 
Clausing, K. A. (2013). Who pays the corporate tax in a global economy? National Tax Journal, 66(1), $151-184$.

Cnossen, S. (1997). The role of the corporation tax in OECD member countries. In J. Head \& R. Krever (Eds.), Company tax systems (pp. 49-84). Melbourne: Fiscal Publications.

Cnossen, S. (2000). Taxing capital income in the Nordic countries: A model for the European Union? chapter 8. In S. Cnossen (Ed.), Taxing capital income in the European Union: Issues and options for reform (pp. 180-213). Oxford: Oxford University Press.

Cnossen, S. (2003). Is the VAT's sixth directive becoming an anachronism? Bulletin for International Fiscal Documentation, 43(12), 434-442.

Cnossen, S. (2005). The future of corporate income taxation in the European Union. In Capital taxation after EU enlargement, proceedings of OeNb workshops. Vienna: Oesterreichische Nationalbank.

Cnossen, S. (2015). What kind of corporation tax regime? Osgoode Hall Law Journal, 52(2), 513-551.

Cnossen, S., \& Bovenberg, A. L. (1997). The Ruding report: Some further thoughts. In M. I. Blejer \& T. Ter-Minassian (Eds.), Macroeconomic dimensions of public finance: Essays in honour of Vito Tanzi (pp. 164-178). London: Routledge.

Cnossen, S., \& Bovenberg, L. (2001). Fundamental tax reform in the Netherlands. International Tax and Public Finance, 8(4), 471-484.

Cooper, M., McClelland, J., Pearce, J., Prisinzano, R., Sullivan, J., Yagan, D., Zidar, O., \& Zwick, E. (2015). Business in the United States: Who owns it and how much tax do they pay? NBER Working Paper Series, Working Paper 21651.

Cui, W. (2017). Destination-based cash-flow taxation: A critical appraisal. University of Toronto Law Journal, 67, 2.

De Mooij, R. A. (2012). Tax biases to debt finance: Assessing the problem, finding solutions. Fiscal Studies, 33(4), 489-512.

De Mooij, R. A., \& Devereux, M. P. (2009). Alternative systems of business tax in Europe: An applied analysis of ACE and CBIT reforms, Working Paper No. 17. Brussels: European Commission.

De Mooij, R. A., \& Devereux, M. P. (2011). An applied analysis of ACE and CBIT reforms in the EU. International Tax and Public Finance, 18, 93-120.

Desai, M. A., \& Hines, J, Jr. (2003). Evaluating international tax reform. National Tax Journal, 56, 487-502.

Devereux, M., \& Freeman, H. (1991). A general neutral profits tax. Fiscal Studies, 12(3), 1-15.

Devereux, M. P., \& Sørensen, P. B. (2006). The corporate income tax: International trends and options for fundamental reform, Economic Papers No. 264. Brussels: European Commission, Directorate-General for Economic and Financial Affairs.

Egger, P., \& Ruff, H. (2015). Tax rate and tax base competition for foreign direct investment. International Tax and Public Finance, 22, 777-810.

Eggert, W., \& Genser, B. (2005). Dual income taxation in EU member countries. CESifo DICE Report, 3(1), 41-47.

Ernst \& Young. (2017a). Worldwide corporate tax guide 2016-2017. Available on the internet.

Ernst \& Young. (2017b). Worldwide personal tax guide: Income tax, social security and immigration 20152016. Available on the internet.

European Commission. (1998). Code of Conduct, based on the conclusions of the ECOFIN Council Meeting concerning taxation policy. Official Journal of the European Communities (98/C 2/01).

European Commission. (2001). Communication from the Commission to the Council, the European Parliament and the Economic and Social Committee-Towards an Internal Market without tax obstacles-A strategy for providing companies with a consolidated corporate tax base for their EU-wide activities. Brussels, COM(2001) 582.

European Commission. (2011). Proposal for a council directive on a common consolidated corporate tax base. Brussels: $\operatorname{COM}(2011) 121$ final.

European Commission. (2014). A study on R\&D tax incentives, Final Report, Taxation Paper N. 52. Luxembourg: Official Publications of the European Communities.

European Commission. (2015). Corporate income taxation in the European Union. Commission Staff Working Document, Brussels: COM(2015) 302 final.

European Commission. (2016a). Proposal for a council directive on a common corporate tax base. Brussels: $\operatorname{COM}(2016) 685$ final.

European Commission. (2016b). Taxation trends in the European Union: Data for the EU member states, Iceland and Norway. DG Taxation and Customs Union, 2016 edition. 
European Council. (1990). Parent-subsidiary directive 90/435/EC of 23 July 1990 on the common system of taxation applicable in the case of parent companies and subsidiaries of different member states, amended on 22 December 2003 (2003/123/EC) and on 20 November 2006 (2006/98/EC).

European Council. (2003a). Interest and Royalty Directive 2003/49/EC of 3 June 2003 on a common system of taxation applicable to interest and royalty payments made between associated companies of different Member States.

European Council. (2003b). Savings directive 2003/48/EC of 3 June 2003 on taxation of savings income in the form of interest payments.

European Council. (2009). Merger directive 2009/133/EC of 19 October 2009 on the common system of taxation applicable to mergers, divisions, partial divisions, transfers of assets and exchanges of shares concerning companies of different Member States.

European Court of Justice. (2004). Manninen, Case C-319/02, September 7.

Evers, L., Millar, H., \& Spengel, C. (2015). Intellectual property box regimes: Effective tax rates and tax policy considerations. International Tax and Public Finance, 22(3), 502-530.

Finke, K., Fuest, C., Nusser, H., \& Spengel, C. (2014). Extending taxation of interest and royalty income at source-An option to limit base Erosion and profit shifting? ZEW Discussion Papers, No. 14-073. Center for European Economic Research, University of Mannheim.

Gammie, M. (1991). Corporate tax harmonisation: An "ACE" proposal: Harmonising European corporate taxation through an allowance for corporate equity. European Taxation, 31(8), 238-242.

Garretsen, H., \& Peeters, J. (2007). Capital mobility, agglomeration and corporate tax rates: Is the race to the bottom for real? CESifo Economic Studies, 53(2), 263-293.

Genser, B., \& Reutter, A. (2007). Moving towards dual income taxation in Europe. FinanzArchiv, 63(3), 436-456.

German Council of Economic Experts. (2003). Staatsfinanzen konsolidieren-Steuersystem reformieren, Annual Report 2003/04, as amplified in German Council of Economic Experts and Max Planck Institute for Intellectual Property, Dual Income Tax: A Proposal for Reforming Corporate and Personal Income Tax in Germany, ZEW Economic Studies.

Goode, R. (1975). The individual income tax. Washington, DC: Brookings Institution.

Gordon, R. H., \& Hausman, J. (2010). Commentary. In J. Mirrlees, et al. (Eds.), Dimensions of tax design: The Mirrlees review. Oxford: Oxford University Press for the Institute for Fiscal Studies.

Gravelle, J., \& Hungerford, T. (2011). Corporate tax reform: Issues for Congress. Washington, DC: Congressional Research Service.

Griffith, R., \& Miller, H. (2014). Taxable corporate profits. Fiscal Studies, 35(4), 535-557.

Griffith, R., Hines, J. R., \& Sørensen, P. B. (2010). International capital taxation. In J. Mirrlees, et al. (Eds.), Dimensions of tax design: The Mirrlees review. Oxford: Oxford University Press.

Hall, R. E., \& Rabushka, A. (1995). The flat tax (2nd ed.). Stanford, CA: Hoover Institution Press.

Harding, M. (2013). Taxation of dividend, interest, and capital gain income, OECD Working Papers, No. 19. Paris: OECD Publishing.

Head, J. G. (1997). Company tax structure and company tax incidence. International Tax and Public Finance, 4, 61-100.

Horst, T. (1980). A note on the international taxation of investment income. Quarterly Journal of Economics, 94, 793-798.

IFS Capital Taxes Group. (1989). Neutrality in the taxation of savings: An extended role for PEPs, Commentary no. 17. London: Institute for Fiscal Studies.

IMF. (2014). Spillovers in international corporate taxation. Washington, DC: IMF Policy Paper.

IMF. (2016). Tax policy, leverage and macroeconomic stability. Washington, DC: Staff Report.

Institute for Fiscal Studies. (1991). Equity for companies: A corporation tax for the 1990s, IFS Commentary No. 26. London: Institute for Fiscal Studies.

Juranek, S., Schindler, D., \& Schjelderup, G. (2016). Taxing royalty payments, Discussion Paper FOR 16 2016. Bergen: Norwegian School of Economics.

Keen, M., \& King, J. (2002). The Croatian profit tax: An ACE in practice. Fiscal Studies, 23(3), 401-418.

Keuschnigg, C., \& Dietz, M. D. (2007). A growth-oriented dual income tax. International Tax and Public Finance, 14, 191-221.

Kleinbard, E. D. (2010). An American dual income tax: Nordic precedents. Northwestern Journal of Law \& Social Policy, 5(1), 40-86.

Leibrecht, M., \& Hochgatterer, C. (2012). Tax competition as a cause of falling corporate income tax rates: A survey of empirical literature. Journal of Economic Surveys, 26(4), 616-648. 
Lodin, S.-O. (2011). Intragroup lending in Sweden-A vehicle for international tax arbitrage. Tax Notes International, 63, 177-180.

Lodin, S.-O. (2013). Intragroup royalties as a vehicle for international tax arbitrage. Tax Notes International, 71, 1317-1319.

McLure, C. E, Jr. (1979). Must corporate income be taxed twice? Washington, DC: Brookings Institution.

McLure, C. E, Jr., \& Weiner, J. M. (2000). Deciding whether the European Union should adopt formulary apportionment of company income, chapter 10. In S. Cnossen (Ed.), Taxing capital income in the European Union: Issues and options for reform. Oxford: Oxford University Press.

McLure, C. E, Jr., \& Zodrow, G. R. (1996). A hybrid consumption-based direct tax for Bolivia. International Tax and Public Finance, 3, 97-112.

Meade Committee. (1978). The structure and reform of direct taxation. London: Allen and Unwin.

Mintz, J. (2015). An agenda for corporate tax reform in Canada. Canadian Council of Chief Executives.

Mintz, J., \& Weiner, J. M. (2003). Exploring formula allocation for the European Union. International Tax and Public Finance, 10(6), 695-711.

Mirrlees, J., et al. (2010). Dimensions of tax design: The Mirrlees review. Oxford: Oxford University Press.

Mirrlees, J., et al. (2011). Tax by design: The Mirrlees report. Oxford: Oxford University Press.

Musgrave, R. A. (1969). Fiscal systems. New Haven: Yale University Press.

Musgrave, R. A., \& Musgrave, P. B. (1984). Public finance in theory and practice. New York: McGraw-Hill.

Neumark Committee. (1962). Report of the Fiscal and Financial Committee. In International Bureau of Fiscal Documentation: EEC Reports on Tax Harmonization, unofficial translation by H. Thurston, Amsterdam (1963).

OECD. (2007). Fundamental reform of corporate income tax. Paris.

OECD. (2008). Setting tax policies that support the Nordic model, chapter 3. In OECD Economic Surveys: Finland (pp. 55-83).

OECD. (2010). Model convention with respect to taxes on income and on capital. Paris.

OECD. (2014). OECD international direct investment statistics 2014. Paris: OECD Publishing.

Patel, E., \& McClelland, J. (2017). What would a cash flow tax look like for U.S. companies? Lessons from a Historical Panel, Working Paper 116. Washington DC: Office of Tax Analysis, U.S. Department of the Treasury.

Pirttilä, J., \& Selin, H. (2011). Income shifting within a dual income tax system: Evidence from the Finnish tax reform of 1993. Scandinavian Journal of Economics, 113(1), 120-144.

Royal (Carter) Commission on Taxation. (1966). Report. Ottawa: Queen's Printer.

Ruding Committee. (1992). Company taxation in the internal market COM(2001) 582final. Brussels: European Commission.

Ryan, P. (2016). A better way: Our vision for a confident America, Tax (June 24). Washington, DC.

Saez, E., \& Stantcheva, S. (2017). A simpler theory of optimal capital taxation, NBER Working Paper 22664. Boston, MA: NBER.

Sinn, H.-W. (2004). Ist Deutschland Noch zu Retten? (5th ed.). Munich: Econ Verlag.

Slemrod, J. L. (1995). Free trade taxation and protectionist taxation. International Tax and Public Finance, 2, 471-489.

Sørensen, P. B. (1994). From the global income tax to the dual income tax: Recent tax reforms in the Nordic countries. International Tax and Public Finance, 1(1), 57-79.

Sørensen, P. B. (2005). Neutral taxation of shareholder income. International Tax and Public Finance, 12, 777-801.

Sørensen, P. B. (2007). The Nordic dual income tax: Principles, practices, and relevance for Canada. Canadian Tax Journal, 55(3), 557-601.

Sørensen, P. B. (2010). Dual income taxes: A Nordic system, chapter 5. In I. Claus, N. Gemmell, M. Harding, \& D. White (Eds.), Tax reform in open economies. London: Edward Elgar.

Spengel, C., \& Wiegard, W. (2004). Dual income tax: A pragmatic tax reform proposal for Germany. CESifo Dice Report, Journal for Institutional Comparisons, 2(3), 9-14.

Treaty of Rome. (1957). Treaty establishing the European Economic Community (EEC Treaty), EUR-LEX. Treaty of Maastricht. (1992). Treaty on European Union, EUR-LEX.

Treaty on European Union. (2012). Consolidated version following the Treaty of Lisbon, EUR-LEX.

US Department of the Treasury. (1977). Blueprints for basic tax reform. Washington, DC: US Government Printing Office.

US Department of the Treasury. (1992). Integration of the individual and corporate tax systems: Taxing business income once. Washington, DC: US Government Printing Office. 
Van den Tempel, A. J. (1970). Corporation tax and individual income tax in the European Communities. Brussels: Commission of the European Communities.

Zodrow, G. R. (2006). Capital mobility and source-based taxation of capital income in small open economies. International Tax and Public Finance, 13, 269-294.

Zodrow, G. R. (2010). International taxation and company tax policy in small open economies, chapter 6. In I. Claus, N. Gemmell, M. Harding, \& D. White (Eds.), Tax reform in open economies. London: Edward Elgar. 